\title{
De relatie tussen baanontevredenheid en vertrekintenties: maakt opleiding een verschil?
}

\author{
Luc Dorenbosch, Rien Huiskamp \& Peter Smulders*
}

In deze bijdrage gaan we in op de rol van opleiding in de relatie tussen ontevredenheid met het werk en de intentie om te vertrekken. In het eerste deel van deze cross-sectionele studie is daartoe onder 15.661 werknemers onderzocht of determinanten van baanontevredenheid anders zijn voor lageropgeleiden omdat deze andere werkwaarden hebben dan hogeropgeleiden. In het tweede deel is onder 13.528 werknemers getoetst of de relatie tussen baanontevredenheid en de manifestatie van vertrek (vertrekintentie en zoekgedrag) afhankelijk is van het opleidingsniveau. Hiërarchische en multinominale regressie analyses op data van de Nationale Enquête Arbeidsomstandigheden (NEA) uit 2007 laten zien dat opleiding een verschil maakt in wat werknemers ontevreden maakt in het werk en in hoeverre ontevredenheid aanzet tot het zoeken naar een andere baan bij een andere werkgever. Voor lageropgeleide werknemers is vooral het gebrek aan extrinsieke werkkenmerken een bron van baanontevredenheid, terwijl dat voor hogeropgeleiden het gebrek aan intrinsieke werkkenmerken is. Verder blijken ontevreden hogeropgeleiden meer werk te maken van het zoeken naar een andere baan dan ontevreden lageropgeleiden. De resultaten laten daarmee zien dat lageropgeleiden een groter risico lopen om vast te komen zitten in een baan die hen niet (meer) past.

\section{Inleiding}

Baantevredenheid hangt mede af van de arbeidsgerelateerde behoeften of werkwaarden van werknemers (Knoop, 1994). De mate waarin werkkenmerken naar tevredenheid aansluiten bij waar werknemers waarde aan hechten wordt in de wetenschappelijke literatuur getypeerd als een supplies-values fit (e.g. Edwards, 1991; Evers, Ybema \& Smulders, 2006) als onderdeel van person-job fit literatuur (Caplan, 1983). Organisaties die zodoende een goede fit of aansluiting tussen werk en werkwaarden weten na te streven zouden het welbevinden en werkprestaties van werknemers bevorderen evenals het verzuim en vertrekintenties verminderen (Kristof-Brown, Zimmerman \& Johnson, 2005). Het vormt bijvoorbeeld de aanleiding voor de recente aandacht voor levensfasebewust personeelsbeleid waarmee organisaties mede inspelen op werkwaarden die met het doorlopen van verschillende levensfases veranderen (Nauta, de Lange \& Görtz, 2010).

* De auteurs zijn allen verbonden aan TNO. Correspondentie: Luc.dorenbosch@tno.nl TNO 
Deze bijdrage richt zich specifiek op de rol die opleiding speelt bij de ontevredenheid met verschillende werkkenmerken en relatie met de vertrekintentie van werknemers. Is er een verschil tussen lageropgeleiden en hogeropgeleiden in wat men belangrijk vindt in het werk en maakt het opleidingsniveau uit in hoezeer onvervulde werkwaarden een vertrekreden vormen? Op basis van een vaak gebruikte typologie (Ross, Schwartz \& Surkiss, 1999) die onderscheid maakt tussen intrinsieke, extrinsieke, en sociale werkwaarden tonen enkele studies (Halman \& Muller, 2006; Warr, 2008) dat lageropgeleiden meer waarde hechten aan de extrinsieke werkkenmerken (salaris, comfort) terwijl hoogopgeleiden meer waarde hechten aan intrinsieke werkkenmerken (autonomie, taakvariëteit).

Als werkwaarden inderdaad voor een deel afhankelijk zijn van het opleidingsniveau dan is de verwachting dat, bij een gebrek aan bepaalde werkkenmerken, lageropgeleiden andere vertrekredenen hebben dan hogeropgeleiden. In het eerste deel van dit artikel bekijken we daarom of lageropgeleiden mogelijk andere redenen hebben om ontevreden te zijn met hun werk dan hogeropgeleiden. Onderzoek naar de determinanten van vertrekintenties wijst deze algemene baanontevredenheid aan als belangrijkste voorspeller van de intentie de werkgever te verlaten (Griffeth, Hom \& Gaertner, 2000). Dat lijkt een open deur, maar is niet altijd vanzelfsprekend. Het psychologische vertrekproces tussen baanontevredenheid, het nadenken over een andere baan en het daadwerkelijk zoeken naar een nieuwe baan kan tot stilstand komen omdat er een oplossing wordt gevonden voor de potentiële vertrekreden (bijvoorbeeld een loonsverhoging). Stilstand kan ook een gevolg zijn van een gebrek aan loopbaanvaardigheden om een nieuwe baan te vinden, of door de verwachting en het geleidelijke inzicht dat de kansen op een goede andere baan schaars zijn (Vandenberg \& Nelson, 1999; Forrier \& Sels, 2005). In dat geval lopen werknemers het risico vast te komen zitten in een baan die ze niet meer past. Lageropgeleiden blijken vaker tot deze groep te behoren dan hogeropgeleiden. Ze vertonen minder zoekgedrag en zijn minder mobiel, maar niet omdat ze meer tevreden zijn (Gesthuizen et al., 2005; Zwinkels, Ooms \& Sanders, 2009). De zwakkere (relatieve) arbeidsmarktpositie zou maken dat ontevreden lageropgeleide werknemers mogelijk moeilijker aan niet passende baan kunnen ontsnappen dan hogeropgeleiden.

Toch blijkt het empirisch onderzoek naar de specifieke rol van opleiding in de relatie tussen baanontevredenheid en vertrekintentie nog schaars (met uitzondering van Gesthuizen, 2009). In het tweede deel van dit artikel onderzoeken we daarom of de mate waarin werknemers een misfit proberen te herstellen door het zoeken naar een andere baan afhangt van het opleidingsniveau. Hiertoe worden er in deze bijdrage drie groepen in verschillende stadia van het vertrekproces onderscheiden: 'blijvers', 'denkers' en 'zoekers'. Dit sluit aan bij Blau (1993; 1994) die een gefaseerde benadering van vertrek hanteert. Deze start bij de vertrekwens (besluiten dat je weg wilt), vervolgens overgaat in voorbereidende activiteiten (bekijken welke mogelijkheden er zijn) om uiteindelijk de aanzet te geven tot actief zoek- en loopbaangedrag (jezelf richten op de toegang tot een andere baan). In deze bijdrage proberen we zodoende een beter licht te werpen op de verschillen tussen lager- en hogeropgeleiden in de vertrekredenen en het vertrekproces. 
De centrale onderzoeksvraag luidt: Is er een verschil tussen lager- en hogeropgeleiden in (1) welke (absente) werkenmerken relateren aan baanontevredenheid en (2) hoe sterk baanontevredenheid weet te differentiëren tussen willen blijven, enkel nadenken over een andere baan en daadwerkelijk zoeken naar andere baan bij een andere werkgever?

\section{Theoretische achtergrond}

\section{Werkkenmerken, opleiding en de relatie met baanontevredenheid}

Vandenberg en Nelson (1999) wijzen in hun onderzoek naar de determinanten van vertrekintenties op het belang van het onderscheiden van verschillende facetten van baanontevredenheid: bijvoorbeeld ontevredenheid met het salaris, met de variatie in het werk of met de leidinggevende. Om het vertrekproces goed te begrijpen achten Vandenberg en Nelson (1999) het noodzakelijk om specifieke vertrekmotieven te onderkennen, omdat ze kunnen verschillen tussen individuele werknemers. Ontevreden zijn met het werk betekent voor de een dat men geen afwisselend werk heeft, terwijl de ander ontevreden is met het werk vanwege het (te) lage salaris dat er tegenover staat. Of er een relatie is tussen dergelijke aspecten van het werk en baanontevredenheid hangt mogelijk af van de specifieke werkwaarden of werkbehoeften die werknemers hebben (Edwards, 1991). Nederlands onderzoek naar het samenspel tussen werkkenmerken en werkwaarden laat bijvoorbeeld zien dat werknemers positiever reageren op het hebben van variatie in het werk naarmate men ook veel belang hecht aan afwisseling in het werk (Evers, Ybema \& Smulders, 2006).

In work values onderzoek wordt daarnaast ook gezocht naar sociale en demografische categorieën die differentiëren in wat bepaalde werknemergroepen belangrijk vinden in hun werk. Warr (2008) toont met Europese data uit de grootschalige World Values Study verschillen in werkwaarden naar opleidingsniveau. Zo blijken lageropgeleiden meer waarde te hechten aan een goed salaris, goede baanzekerheid, goede werktijden en een niet te hoge werkdruk. Voor hogeropgeleiden zijn interessant werk, uitdaging, autonomie, promotiemogelijkheden en het gevoel iets met het werk te kunnen bereiken belangrijker dan voor lageropgeleiden. Dit toont het beeld van een veelvuldig gemaakte onderscheid tussen extrinsieke en intrinsieke werkwaarden (Yankelovich et al., 1985; Inglehart, Basáñez \& Moreno, 1998; Van Hoof, 2002). Hierbij hechten lageropgeleiden meer waarde aan extrinsieke of instrumentele werkwaarden, waarbij werk dient als een middel tot het nastreven van doelen buiten het werk en waarvoor een gegarandeerd inkomen en niet al teveel werkongemak een instrumenteel karakter heeft. Hoogopgeleiden hechten echter meer waarde aan intrinsieke of expressieve werkaspecten waarbij werk wordt beschouwd als een middel tot het vervullen van de expressieve behoeften op het gebied van persoonlijke groei, ontplooiing en zelfactualisatie.

Hoewel empirisch onderzoek schaars is, vinden ook andere studies dezelfde relatie tussen het opleidingsniveau en het type werkwaarden dat men heeft (Harding \& Hikspoors, 1995; Halman \& Muller, 2006; Van den Broeck, van Ruysseveldt, Smulders \& de Witte, in druk). Ross, Schwartz en Surkiss (1999) voegen er op 
basis van andere classificaties nog een derde categorie werkwaarden aan toe: sociale of relationele werkwaarden. Op deze waarden vindt Warr (2008) echter geen onderscheid tussen lager- en hogeropgeleiden. In lijn met dit onderzoek is het aannemelijk dat de baanontevredenheid van hogeropgeleiden van andere werkkenmerken afhangt dan van lageropgeleiden. Werkaspecten die relateren aan baanontevredenheid liggen bij laagopgeleiden meer op het extrinsieke vlak, terwijl voor hoogopgeleiden het gebrek aan de intrinsieke werkkenmerken relateert aan meer baanontevredenheid. Op het sociale vlak verwachten we geen verschillen tussen opleidingsniveaus. Derhalve luiden de hypotheses:

H1: Bij lageropgeleiden zal het gebrek aan extrinsieke/instrumentele werkkenmerken sterker relateren aan baanontevredenheid dan bij hogeropgeleiden.

H2: Bij hogeropgeleiden zal het gebrek aan intrinsieke/expressieve werkkenmerken sterker relateren aan baanontevredenheid dan bij lageropgeleiden.

H3: Er is geen verschil tussen lager- en hogeropgeleiden in hoe sterk het gebrek aan sociale/relationele werkkenmerken relateert aan baanontevredenheid

\section{Baanontevredenheid, opleiding en de manifestatie van vertrek}

Human capital theorie (Becker, 1964; Mincer, 1974) stelt dat werknemers met een hogere opleiding een hoger niveau aan kennis en vaardigheden hebben vergaard wat hen aantrekkelijker maakt voor (andere) werkgevers en meer kansen op de arbeidsmarkt biedt. Daarbij hebben hogeropgeleiden de keuze om in het geval van een slechte arbeidsmarkt ook onder hun opleidingsniveau een baan te accepteren. Naarmate de opleiding lager is worden de arbeidsmarktkansen zodoende kleiner (Büchel, De Grip \& Mertens, 2003). Longitudinaal onderzoek van Sanders en De Grip (2004) liet zien dat bij laagopgeleide werknemers de deelname aan training wel de kansen op de interne arbeidsmarkt vergrootte, maar geen effect had op het vertrek naar een andere werkgever. Ondanks investeringen in het eigen menselijk kapitaal lijkt het vertrek naar een andere werkgever voor laagopgeleiden een moeilijke opgaaf. Gesthuizen en Dagevos (2005) maken een onderscheid tussen 'vastzittenden' en 'verbetering zoekenden'. Vastzittende werknemers hebben negatieve redenen om te vertrekken bij de werkgever, maar tonen hiertoe geen zoekgedrag. Werknemers die zoeken naar verbetering hebben ook negatieve redenen om te willen vertrekken, maar zoeken wel actief naar een andere baan. Hierbij bleek dat laagopgeleide werknemers ten opzichte van hogeropgeleiden de grootste kans hebben te behoren tot de groep 'vastzittenden' in plaats van tot de groep 'verbetering zoekenden'. De mate waarin een zwakkere arbeidsmarktpositie de kans verkleint dat lageropgeleiden in staat zijn een andere baan te vinden, kan er dus toe leiden dat deze groep in het geval van onvrede met het werk wel weg wil zonder daar actie op te ondernemen. Raemdonck et al. (2008) vonden in hun onderzoek onder laagopgeleiden in België dat ook werknemers die meer zelfsturend waren niet beter in staat bleken om hun wens om weg te willen te realiseren (in de vorm van vertrek) dan werknemers met dezelfde verloopintentie die minder zelfsturend waren. Zelfs met een actieve loopbaanhouding, blijken de kansen van laagopgeleide werknemers op de externe arbeidsmarkt begrensd. 
Lageropgeleiden zullen hierdoor hun kansen op een andere baan mogelijk lager inschatten en daardoor vaker afzien van actief zoeken naar een andere, betere baan. Dit sluit aan bij de klassieke expectancy-theorie (Vroom, 1964) waarin wordt gesteld dat naast de motivatie om te (vertrek)gedrag te vertonen, mensen ook de verwachting moeten hebben dat dit gedrag wat oplevert. De relatie tussen baanontevredenheid en het zoeken naar een andere baan kan daardoor verschillen tussen lager- en hogeropgeleiden. We verwachten in lijn met het psychologische vertrekproces (waarbij werknemers zijn onderverdeeld in 'blijvers', 'denkers' en 'zoekers') dat baanontevredenheid voor iedere werknemer relateert aan een hogere verloopintentie en denken over een nieuwe baan (van blijven naar denken), maar dat het slechts voor hogeropgeleiden relateert aan daadwerkelijk zoekgedrag (van blijven en denken naar zoeken). De hypotheses hierbij zijn:

H4: Er is geen verschil tussen lager- en hogeropgeleiden in hoe sterk baanontevredenheid weet te differentiëren tussen het willen blijven bij een werkgever en het nadenken over een andere baan.

H5: Ontevreden hogeropgeleiden zullen vaker de stap zetten van het willen blijven bij een werkgever naar het zoeken van een andere baan dan lageropgeleiden.

H6: Ontevreden hogeropgeleiden zullen ook vaker de stap zetten van het nadenken over een andere baan naar het zoeken van een andere baan dan lageropgeleiden.

\section{Methode van Onderzoek}

\section{Databestand en steekproefselectie}

In dit onderzoek zijn secundaire analyses gedaan op het databestand van de Nationale Enquête Arbeidsomstandigheden (NEA) van TNO uit 2007. Het totale bestand omvat zelfgerapporteerde werknemerdata $(\mathrm{N}=22.759)$ op basis van vragenlijsten en is representatief voor de Nederlandse beroepsbevolking tussen de 15 en 64 jaar, exclusief zelfstandigen. Voor meer informatie over de opzet van de NEA en de gehanteerde steekproeftrekking verwijzen we naar Van den Bossche, Hupkens, de Ree en Smulders (2007).

Voor de eerste onderzoeksvraag in deze studie is voor het onderzoeken van de determinanten van baanontevredenheid gebruik gemaakt van het totale databestand, waarbij de data van in totaal 15.661 werknemers uiteindelijk bruikbaar bleek voor analyse.

Ten behoeve van de tweede onderzoeksvraag zijn 'blijvers', 'denkers' en 'zoekers' ingedeeld op basis van "ja/nee” antwoorden op drie NEA vragen. Op basis van het antwoordpatroon van respondenten op de drie vragen (zie tabel 1) is een selectie gemaakt. Uiteindelijk waren 13.538 werknemers in te delen als blijvers $(\mathrm{N}=7.899)$, denkers $(\mathrm{N}=2.454)$ of zoekers $(\mathrm{N}=3.185)$. Werknemers met een andere antwoordcombinatie zijn buiten dit onderzoeksdeel gelaten. De 3 geselecteerde groepen corresponderen zodoende met 3 verschillende fases in het vertrekproces: (1) werknemers die willen blijven bij hun werkgever ('blijvers'), 
(2) werknemers die weg willen, maar enkel nagedacht hebben over een andere baan ('denkers') en (3) werknemers die zowel nagedacht hebben als daadwerkelijk zoeken naar een andere baan bij een andere werkgever ('zoekers').

\section{Tabel 1 Indeling blijvers, denkers en zoekers o.b.v. 3 antwoordcombinaties}

\begin{tabular}{|c|c|c|c|}
\hline & $\begin{array}{l}\text { 'Zou u, als het aan u lag, } \\
\text { over } 5 \text { jaar nog bij dit } \\
\text { bedrijf werken?' }\end{array}$ & $\begin{array}{l}\text { 'Heeft u er in het afgelopen } \\
\text { jaar over nagedacht om ander } \\
\text { werk te zoeken dan het werk } \\
\text { bij uw huidige werkgever?' }\end{array}$ & $\begin{array}{l}\text { 'Heeft u in het afgelopen } \\
\text { jaar ook daadwerkelijk } \\
\text { iets ondernomen om } \\
\text { ander werk te vinden?' }\end{array}$ \\
\hline Blijvers & $\mathrm{Ja}$ & Nee & Nee \\
\hline Denkers & Nee & $\mathrm{Ja}$ & Nee \\
\hline Zoekers & $\mathrm{Nee}$ & Ja & $\mathrm{ja}$ \\
\hline
\end{tabular}

\section{Meetinstrumenten}

Hieronder beschrijven we gebruikte meetinstrumenten in dit onderzoek. Tabel 2 toont een overzicht van de verschillende variabelen, gemiddeldes, standaarddeviaties en (waar het schalen betreft) chronbachs alfa's. Voor meer informatie over de achtergrond en de kwaliteit van de gebruikte meetinstrumenten verwijzen we ook hier naar Van den Bossche et al. (2007).

\section{- Baanontevredenheid}

Algemene baanontevredenheid is gemeten aan de hand van één item op een vijfpuntsschaal ( $1=$ 'zeer tevreden' tot 5 = 'zeer ontevreden'). Het item luidt: 'In welke mate bent u tevreden met uw werk?'. Wanous, Reichers en Hudy (1997) laten zien dat 1-item maten een acceptabele betrouwbaarheid en validiteit hebben.

- Extrinsieke, intrinsieke en sociale werkkenmerken

De werkkenmerken bevraagd in dit onderzoek corresponderen met eerdere classificaties van extrinsieke, intrinsieke en sociale werkkenmerken (Kalleberg, 1977; Ross et al., 1999; Halman \& Muller, 2006). Voor het meten van het gebrek aan extrinsieke/expressieve werkkenmerken zijn drie aparte variabelen opgenomen ('salarisontevredenheid', 'werkonzekerheid' en 'werkdruk'). Alleen voor werkdruk is een schaal meegenomen die de taakeisen meet. Deze heeft een goede betrouwbaarheid.

Voor het meten van van het gebrek aan intrinsieke/expressieve werkkenmerken zijn ook drie afzonderlijke variabelen opgenomen: 'taakvariatie', 'taakautonomie' en 'loopbaanmogelijkheden'. Taakvariatie en taakautonomie betreffen twee schalen met redelijk tot goede betrouwbaarheden (tussen de .70 en .80).

Sociale/relationele werkkenmerken zijn gemeten aan de hand van de schalen 'sociale steun van leidinggevenden' en 'sociale steun van collega's'. Het betreft hier twee schalen van ieder 4 items met een goede betrouwbaarheid. Vanwege de onderzoeksinsteek om werkkenmerken te benaderen als redenen van baanontevredenheid zijn ze (waar nodig) voor deze studie omgescoord zodat een hoge 
Tabel 2 Kengetallen per hoofdvariabele: aantal items,omschrijving, gemiddelde, standaarddeviatie (sd) en Cronbach's alfa $(\alpha)$

\begin{tabular}{|c|c|c|c|c|c|}
\hline Variabele & $\begin{array}{l}\text { \# } \\
\text { Items }\end{array}$ & Omschrijving & $\begin{array}{l}\text { Antwoord Catego- } \\
\text { rieën }\end{array}$ & $\begin{array}{l}\text { Gemid- } \\
\text { delde } \\
\text { (sd) }\end{array}$ & $\alpha$ \\
\hline $\begin{array}{l}\text { Baanontevre- } \\
\text { denheid }\end{array}$ & 1 & $\begin{array}{l}\text { Algemene dissatisfactie } \\
\text { met het werk }\end{array}$ & $\begin{array}{l}\text { I = zeer tevreden; } \\
5 \text { = zeer ontevreden }\end{array}$ & $2,15(0,78)$ & - \\
\hline $\begin{array}{l}\text { Salarisontevre- } \\
\text { denheid }\end{array}$ & I & Rapportcijfer salaris & $\begin{array}{l}\text { I = zeer voldoende; } \\
4 \text { = zeer onvoldoende }\end{array}$ & $2,06(0.91)$ & - \\
\hline Hoge Taakeisen & 4 & $\begin{array}{l}\text { Snel/hard/veel//hectisch } \\
\text { werk }\end{array}$ & $\begin{array}{l}I=\text { nooit; } \\
4=\text { altijd }\end{array}$ & $2,42(0,67)$ & .85 \\
\hline $\begin{array}{l}\text { Werkonzeker- } \\
\text { heid }\end{array}$ & I & $\begin{array}{l}\text { Zorgen maken over } \\
\text { behoud baan }\end{array}$ & $\begin{array}{l}0=\text { nee } \\
\mathrm{I}=\mathrm{ja}\end{array}$ & $0,22(0,42)$ & - \\
\hline $\begin{array}{l}\text { Weinig Taak- } \\
\text { variatie }\end{array}$ & 3 & $\begin{array}{l}\text { Gevarieerd werk met } \\
\text { leermogelijkheden / uitda- } \\
\text { ging }\end{array}$ & $\begin{array}{l}I=\text { altijd; } \\
4=\text { nooit }\end{array}$ & $2,25(0,74)$ & .75 \\
\hline $\begin{array}{l}\text { Weinig Taak- } \\
\text { autonomie }\end{array}$ & 5 & $\begin{array}{l}\text { Zelf beslissen over uitvoe- } \\
\text { ring/volgorde/ werktempo } \\
\text { in het werk }\end{array}$ & $\begin{array}{l}\text { I = meestal; } \\
3=\text { nee }\end{array}$ & $\mathrm{I}, 42(0,57)$ & .76 \\
\hline $\begin{array}{l}\text { Weinig Loop- } \\
\text { baanmogelijk- } \\
\text { heden }\end{array}$ & I & $\begin{array}{l}\text { Rapportcijfer loopbaan- } \\
\text { mogelijkheden }\end{array}$ & $\begin{array}{l}\text { I = zeer voldoende; } \\
4 \text { = zeer onvoldoende }\end{array}$ & $2,4 I(1,02)$ & - \\
\hline $\begin{array}{l}\text { Weinig steun } \\
\text { leidinggevende }\end{array}$ & 4 & $\begin{array}{l}\text { Leidinggevende heeft oog } \\
\text { voor welzijn/ geeft aan- } \\
\text { dacht/biedt hulp }\end{array}$ & $\begin{array}{l}\text { I = helemaal eens; } \\
4 \text { = helemaal oneens }\end{array}$ & $2,05(0,7 \mathrm{I})$ & .88 \\
\hline $\begin{array}{l}\text { Weinig steun } \\
\text { collega's }\end{array}$ & 4 & $\begin{array}{l}\text { Collega's zijn vriendelijk/ } \\
\text { tonen belangstelling }\end{array}$ & $\begin{array}{l}\text { I }=\text { helemaal eens; } \\
4=\text { helemaal oneens }\end{array}$ & $\mathrm{I}, 65(0,54)$ & .83 \\
\hline
\end{tabular}

score betekent dat werknemers een gebrek aan extrinsieke, intrinsieke of sociale werkkenmerken rapporteren.

\section{- Opleidingsniveau}

Voor het meenemen van opleidingsniveau zijn werknemers op basis van hun hoogst afgemaakte opleiding ingedeeld in 4 niveaus ( 0 = 'geen of basisonderwijs'; 1 = 'VBO of MAVO'; 2 = 'HAVO/VWO of MBO'; 3 = '(post-) HBO of universiteit'). In het totale databestand heeft $5 \%$ geen of basisonderwijs als hoogst afgemaakte opleiding, $17 \%$ VBO of MAVO, $41 \%$ MBO of HAVO/VWO en heeft $37 \%$ een HBO of universitair diploma. De verdeling van opleidingsniveaus in de selectie van blijvers, denkers en zoekers wijkt niet af van de verdeling naar opleiding in het totale bestand.

\section{- Controlevariabelen}

In lijn met het werk van Gesthuizen (2009) nemen we een reeks van controlevariabelen mee die naast opleiding een baanontevredenheid mede van invloed kunnen zijn op de manifestatie van vertrek. Zo wordt gecontroleerd voor leeftijd, het 
soort contract (tijdelijk versus vast) en burgerlijke staat (wel versus niet gehuwd/ samenwonend) van werknemers. Ook controleren we voor bedrijfsgrootte, omdat werknemers in kleinere bedrijven meer op de externe arbeidsmarkt zijn aangewezen wanneer zij een misfit zouden willen herstellen in een andere baan (Althauser \& Kalleberg, 1990). Als laatste wordt gecontroleerd voor de sector van activiteit onderverdeeld in 'semi-overheid' (zorg en onderwijs), 'industrie', 'diensten' en 'agrarisch' met 'overheid' als referentiecategorie.

\section{Statistische analyses}

Voor het toetsen van de hypotheses 1, 2 en 3 met betrekking tot de verschillen tussen lager- en hogeropgeleiden in de redenen van ontevredenheid met het werk, maken we gebruik van een multivariate regressieanalyse met baanontevredenheid als afhankelijke variabele. In de tweede stap worden de interacties van opleidingsniveau met de verschillende extrinsieke, intrinsieke en sociale werkkenmerken toegevoegd. Interactietermen zijn geconstrueerd op basis van het product van gecentreerde waardes ( $z$-scores) voor elk van de variabelen om ongewenste afhankelijkheid en multicollineariteit tussen de hoofdfactoren de interactietermen te vermijden (Aiken \& West, 1991). Voor het toetsen van de relatie tussen baanontevredenheid en het nadenken over dan wel zoeken naar een andere baan bij een andere werkgever (hypothese 4, 5, en 6), maken we gebruik van multinominale regressieanalyses. De interactie tussen baanontevredenheid en het opleidingsniveau wordt opgenomen om te toetsen of er een onderscheid is tussen denkers of zoekers ten opzichte van de blijvers (hypothese 4 en 5). In lijn met hypothese 4 verwachten we hier geen significant interactie-effect tussen opleiding en baanontevredenheid voor de denkers (versus de blijvers), maar in lijn met hypothese 5 wel voor de zoekers (versus de blijvers). Voor het toetsen van hypothese 6 , verrichten we een aparte multinominale regressieanalyse waarin zoekers worden afgezet tegen de denkers als referentiegroep. In de analyses is opleidingniveau meegenomen als lineaire variabele (zie ook Gesthuizen, 2009). Daarbij dient opgemerkt te worden dat in de multinominale regressieanalyses de interactieterm van opleiding met baanontevredenheid op een andere manier geconstrueerd is dan bij de multivariate regressieanalyses. Er is gecentreerd door de gemiddeldes op de onafhankelijke variabelen opleiding en baanontevredenheid af te trekken van de individuele scores op deze variabelen, voornamelijk om een mogelijk interactie-effect in een figuur weer te kunnen geven en te interpreteren (zie ook De Vroome, Smulders \& Houtman, 2010).

\section{Resultaten}

In deze resultatensectie bespreken we alleen de relaties zoals deze in de hypotheses aan bod komen. Tabel 3 toont de resultaten van de multivariate regressieanalyse met baanontevredenheid als afhankelijke variabele. Wat als eerste opvalt, is dat opleiding als onafhankelijke variabele geen relatie vertoont met baanontevredenheid ( $\mathrm{B}=.013$; n.s.), terwijl andere socio-demografische variabelen dat wel doen. Verder tonen de regressiegewichten bij elk van de (absente) intrinsieke, 
Tabel 3 Resultaten van de hiërarchische multipele regressieanalyse met baanontevredenheid als afhankelijke variabele $(N=15.661)$

\begin{tabular}{|c|c|c|}
\hline & \multicolumn{2}{|c|}{ Baanontevredenheid } \\
\hline & B & $B$ \\
\hline \multicolumn{3}{|l|}{ Controlevariabelen } \\
\hline Leeftijd & $.033 * *$ & $.032 * *$ \\
\hline Geslacht (man) & $.040 * *$ & $.040 * *$ \\
\hline Contract (tijdelijk) & $-.078 * *$ & $-.077^{* *}$ \\
\hline Opleidingsniveau (OPL) & .013 & .013 \\
\hline \multicolumn{3}{|l|}{ Extrinsieke werkkenmerken } \\
\hline Salarisontevredenheid (SAL) & $.095 * *$ & $.098^{* *}$ \\
\hline Hoge Taakeisen (EIS) & $.094^{* *}$ & $.100 * *$ \\
\hline Werkonzekerheid (ONZ) & $.162 * *$ & $.162^{* *}$ \\
\hline \multicolumn{3}{|l|}{ Intrinsieke werkkenmerken } \\
\hline Weinig Autonomie (AUT) & $.079 * *$ & $.080^{* *}$ \\
\hline Weinig Taakvariatie (VAR) & $.142 * *$ & $.142^{* *}$ \\
\hline Weinig Loopbaanmogelijkheden (LPB) & $.134 * *$ & $\left..13\right|^{* *}$ \\
\hline \multicolumn{3}{|l|}{ Sociale werkkenmerken } \\
\hline Weinig steun leidinggevende (LEI) & $.197 * *$ & $.196 * *$ \\
\hline Weinig steun collega's (COL) & $.137^{* *}$ & $.139 * *$ \\
\hline \multicolumn{3}{|l|}{ Interacties } \\
\hline SAL $\times$ OPL & & $-.015^{*}$ \\
\hline$E I S \times O P L$ & & $-.021 * *$ \\
\hline ONZ $\times$ OPL & & -.005 \\
\hline AUT $\times$ OPL & & .000 \\
\hline VAR $\times$ OPL & & $.015^{*}$ \\
\hline $\mathrm{LPB} \times \mathrm{OPL}$ & & $.023^{* *}$ \\
\hline LEI $\times$ OPL & & .010 \\
\hline COL $\times$ OPL & & -.004 \\
\hline
\end{tabular}

$* \mathrm{p}<.05 ; * * \mathrm{p}<.0 \mathrm{I} ; \mathrm{R}^{2}(\mathrm{MI})=.226 ; \mathrm{R}^{2}(\mathrm{M} 2)=.228$

Bron: NEA (2007)

extrinsieke of sociale werkkenmerken een sterk significante relatie met baanontevredenheid. Onafhankelijk van het opleidingsniveau is het gebrek aan deze werkkenmerken dus gerelateerd aan meer baanontevredenheid. Voegen we in stap 2 de interactietermen toe dan bieden de resultaten redelijke ondersteuning voor de verwachting dat hoogopgeleiden andere redenen voor ontevredenheid kennen dan lageropgeleiden. 
Naarmate de opleiding hoger is zijn werknemers minder ontevreden over hun baan bij salarisontevredenheid $((\mathrm{B}=-.015 ; \mathrm{p}<.05)$ en een hoge werkdruk $(\mathrm{B}=-.021 ; \mathrm{p}<.01)$. Met het afnemen van het opleidingsniveau zouden deze werkkenmerken dus meer ontevreden maken. De relatie tussen baanonzekerheid en baanontevredenheid blijkt niet afhankelijk te zijn van het opleidingsniveau. Verder tonen de interactie-effecten in lijn met hypothese 2 dat het gebrek aan taakvariatie $(\mathrm{B}=.015 ; \mathrm{p}<.05)$ en loopbaanmogelijkheden $(\mathrm{B}=.023 ; \mathrm{p}<.01)$ relateert aan meer ontevredenheid met de baan naarmate het opleidingsniveau hoger is. Voor het gebrek aan autonomie vinden we geen interactie-effect. De baanontevredenheid van hogeropgeleiden lijkt zodoende meer gevoelig te zijn voor het ontbreken van deze intrinsieke werkenmerken dan bij lageropgeleiden. Hypothese 3 stelt dat sociale werkkenmerken voor lager- en hogeropgeleiden even belangrijk te zijn. Hier liggen de resultaten in lijn met de hypothese; we vinden voor zowel het gebrek aan steun van leidinggevenden $(B=.010$; n.s.) en collega's $(B=-.004 ;$ n.s. $)$ geen significante interactie-effecten met opleiding op de mate van baanontevredenheid. Qua verklaarde variantie in baanontevredenheid levert het toevoegen van de interactietermen in stap 2 echter geen grote bijdrage $\left(\Delta \mathrm{R}^{2}=\right.$. 002) aan de reeds verklaarde variantie door de afzonderlijke werkkenmerken $\left(R^{2}\right.$ $=.226$ ). Desondanks geven de resultaten empirische steun aan de stelling dat de absente werkkenmerken die relateren aan baanontevredenheid in de verwachte richting differentiëren tussen opleidingsniveaus.

In welke mate de relatie tussen baanontevredenheid en de manifestatie van vertrek afhankelijk is van het opleidingsniveau toont de multinominale regressieanalyse in Tabel 4. De tabel laat zien in hoeverre de controlevariabelen, opleiding, baanontevredenheid en de interactie tussen baanontevredenheid en opleiding relateren aan het behoren tot de groep 'denkers' of tot de groep 'zoekers' (ten opzichte van het behoren tot de groep 'blijvers'). Voor de hoofdvariabelen opleiding en baanontevredenheid, blijkt dat het opleidingsniveau differentieert tussen zowel blijven en denken $(B=.462 ; \mathrm{p}<.001)$ als tussen blijven en zoeken $(B=.515$; $\mathrm{p}<.001)$. Ongeacht de baanontevredenheid zijn werknemers met een hogere opleiding meer doende met een beweging naar buiten toe dan lageropgeleiden. Baanontevredenheid zelf blijkt veruit de sterkste push-factor te zijn als het gaat om het nadenken over $(B=1.285 ; \mathrm{p}<.001)$ en zoeken naar een andere baan $(\mathrm{B}=1.696 ; \mathrm{p}<.001)$.

Om de rol van opleiding in het vertrekproces te kunnen duiden stellen we in de hypotheses dat de mate waarin baanontevredenheid differentieert tussen blijvers, denkers en zoekers ook afhankelijk is van het opleidingsniveau. Verwacht wordt dat nadenken over een andere baan als gevolg van baanontevredenheid niet opleidingsafhankelijk is (hypothese 4) terwijl het zoeken naar een andere baan dat wel is (hypothese 5). Zoals de resultaten laten zien liggen deze twee interactie-effecten inderdaad in lijn met hypothese 4 en 5 . Baanontevredenheid weet niet beter te differentiëren tussen blijven en denken voor hogeropgeleiden dan voor lageropgeleiden ( $\mathrm{B}=.074$; n.s.). De relatie tussen baanontevredenheid en het vertonen van zoekgedrag (ten opzichte van blijven) lijkt echter wel afhankelijk te zijn van 
Tabel 4 Resultaten van de multinominale logistische regressie analyse met denkers en zoekers als afhankelijke variabelen (referentiegroep: blijvers) $(N=13.538)$

\begin{tabular}{|c|c|c|}
\hline & $\begin{array}{c}\text { Denkers } \\
\text { (vs blijvers) }\end{array}$ & $\begin{array}{c}\text { Zoekers } \\
\text { (vs blijvers) }\end{array}$ \\
\hline & B & B \\
\hline \multicolumn{3}{|l|}{ Leeftijd } \\
\hline \multicolumn{3}{|l|}{ 15-24 jaar (ref) } \\
\hline 25-34 jaar & $-.260 * *$ & .185 \\
\hline $35-44$ jaar & $-.64 I^{* *}$ & -.080 \\
\hline $45-54$ jaar & $-.867 * *$ & $-.632 * *$ \\
\hline $55-64$ jaar & $-1.274 * *$ & $-1.366 * *$ \\
\hline \multicolumn{3}{|l|}{ Geslacht } \\
\hline \multicolumn{3}{|l|}{ Vrouw (ref) } \\
\hline Man & -.085 & .081 \\
\hline \multicolumn{3}{|l|}{ Contract } \\
\hline \multicolumn{3}{|l|}{ Vast contract (ref) } \\
\hline Tijdelijk contract & $.423 * *$ & $.934 * *$ \\
\hline \multicolumn{3}{|l|}{ Burgerlijke staat } \\
\hline \multicolumn{3}{|c|}{ Niet gehuwd/niet samenwonend (ref) } \\
\hline Gehuwd/samenwonend & $-.313^{* *}$ & $-.216 * *$ \\
\hline \multicolumn{3}{|l|}{ Bedrijfsgrootte } \\
\hline \multicolumn{3}{|l|}{ I-9 wns (ref) } \\
\hline $10-49$ wns & .053 & -.010 \\
\hline $50-99$ wns & -.019 & $-.143^{*}$ \\
\hline $100-499$ wns & -.019 & -.021 \\
\hline $500+$ wns & $-.268 * *$ & $-.24 I^{* *}$ \\
\hline \multicolumn{3}{|l|}{ Sectortype } \\
\hline \multicolumn{3}{|l|}{ Overheid (ref) } \\
\hline Semi-overheid & -.132 & $-.27 \mid * *$ \\
\hline Privaat / industrie & .034 & -.160 \\
\hline Privaat / diensten & $.256 * *$ & .124 \\
\hline Privaat / agrarisch & -.357 & -.145 \\
\hline Opleidingsniveau (OPL) & $.462^{* *}$ & $.515 * *$ \\
\hline Baanontevredenheid (DIS) & $1.285 * *$ & $1.696 * *$ \\
\hline DIS $\times$ OPL & .074 & $.128 * *$ \\
\hline
\end{tabular}

$*_{p}<0.05 ; * *<0.01 ;$ Nagelkerke $\mathrm{R}^{2}=.325$

Bron: NEA (2007) 
Figur 1 Grafische weergave van het interactie-effect van het opleidingsniveau op de relatie tussen baanontevredenheid en zoekgedrag (versus blijven)

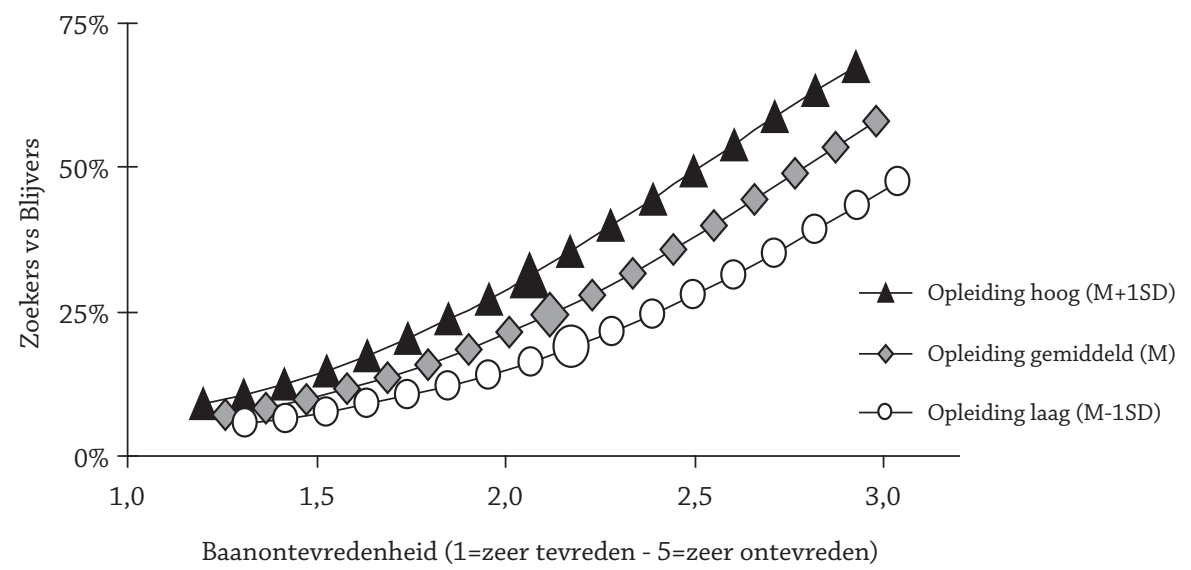

het opleidingsniveau in de verwachte richting $(B=.128 ; \mathrm{p}<.01)$ : hogeropgeleiden zetten baanontevredenheid vaker om in zoekgedrag dan lageropgeleiden (hypothese 5).

Hypothese 6 stelt dat de interactie tussen baanontevredenheid en opleidingsniveau ook moet differentiëren tussen enkel nadenken over een andere baan en het daadwerkelijk zoeken naar een andere baan. Ontevreden hogeropgeleiden zouden minder vaak blijven steken bij het enkel nadenken over een andere baan en dus ook vaker gaan zoeken dan ontevreden lageropgeleide denkers. In een aanvullende analyse (hier niet getoond) waarin de denkers als referentiegroep fungeerde bleek de interactie tussen baanontevredenheid en opleiding niet te differentiëren tussen denken en zoeken ( $B=.055$; n.s.). Dit toont mogelijk dat de Blau's $(1993 ; 1994)$ gefaseerde benadering van vertrek in deze studie niet opgaat. We komen hier in de discussie op terug.

Figuur 1 toont tenslotte het interactieplot behorende bij de hierboven vastgestelde significante interactie tussen baanontevredenheid en opleiding die differentieert tussen blijvers en zoekers. Het interactieplot laat zien dat bij een lage baanontevredenheid het percentueel aandeel dat gaat zoeken in plaats van blijven laag en nagenoeg gelijk is voor de verschillende opleidingsgroepen. Met het toenemen van de baanontevredenheid laat het plot echter zien dat dit bij een hoger opleidingsniveau sterker relateert aan het zoeken naar een andere baan dan bij lageropgeleiden. 


\section{Discussie}

In dit artikel staat baanontevredenheid als een indicator van een gebrekkige aansluiting tussen wat het werk biedt en wat de werknemer behoeft centraal. Om beter zicht te krijgen op wat een gebrekkige aansluiting betekent voor verschillende opleidingsgroepen is onderzocht of lageropgeleiden verschillen van hogeropgeleiden in de redenen die ten grondslag liggen aan baanontevredenheid. Verder is onderzocht of lageropgeleiden verschillen van hogeropgeleiden in het nadenken over of zoeken naar een andere baan wanneer men ontevreden is met de huidige baan.

De resultaten op basis van analyses op een omvangrijk databestand van TNO uit 2007 ondersteunen allereerst dat de baanontevredenheid van laagopgeleiden sterker afhankelijk is van een gebrek aan extrinsiek of instrumenteel waardevolle werkkenmerken zoals een goed salaris en weinig werkdruk (hypothese 1). Bij hogeropgeleiden relateert juist het gebrek aan intrinsieke/expressieve werkkenmerken zoals taakvariatie en loopbaanmogelijkheden aan meer baanontevredenheid (hypothese 2). Verder stelden we dat het gebrek aan sociale en relationele werkkenmerken geen andere relatie heeft met baanontevredenheid voor hogeropgeleiden dan voor lageropgeleiden: geen steun krijgen van collega's en leidinggevenden beschouwd iedereen als ongewenst (hypothese 3). Ook deze hypothese wordt niet verworpen, wat verdere validatie biedt voor het onderscheid tussen intrinsieke en extrinsieke werkwaardes.

De resultaten van dit onderzoek wijzen op een gedifferentieerd patroon van redenen van baanontevredenheid voor werknemers van een verschillend opleidingsniveau. Dit bouwt voort op eerder onderzoek door Evers, Ybema en Smulders (2006) die de interactie tussen werkwaarden en werkkenmerken onderzochten door werknemers expliciet te vragen naar hun werkwaarden (wat vindt u belangrijk in uw werk?). De interactie-effecten op baantevredenheid waren hier weliswaar overtuigender, maar boden geen inzicht in de verschillende werkwaardes van herkenbare personeelsgroepen zoals deze eerder werden gevonden door Warr (2008). Waarom lageropgeleiden minder groeiwensen hebben maar meer waarde hechten aan salaris en lagere taakeisen kent geen eenduidig antwoord. Naast dat groei en carrière maken niet voor iedereen een ambitie is, kan het zijn dat voor lageropgeleiden hoge taakeisen of salarisontevredenheid in praktijk iets anders betekent dan voor hogeropgeleiden. Vooral wanneer hoge taakeisen zich in fysiek zwaarder werk voordoen (dat vaker deel uitmaakt van laagopgeleide beroepen) dan kunnen deze een andere betekenis hebben voor de tevredenheid met het werk dan in beroepen waarin hoge taakeisen minder fysiek belastend zijn. Daarnaast zou salarisontevredenheid iets anders kunnen betekenen bij een lager salaris dan bij een hoger salaris. In het eerste geval betekent het dat je niet krijgt wat je nodig hebt om in essentiële levensbehoeften te voorzien, terwijl bij een hoog salaris de ontevredenheid vooral duidt op de scheve verhouding tussen inspanning en beloning. Meer onderzoek naar de betekenis van werkkenmerken en de factoren die de ontwikkeling van werkbehoeften bij lager- en hogeropgeleiden beïnvloeden is gewenst. 
In het tweede deel van deze bijdrage blijkt dat (in lijn hypothese 4), ongeacht het opleidingsniveau, baanontevredenheid samenhangt met het nadenken over een andere baan ("denken staat vrij"). Wel vinden we dat baanontevredenheid bij hogeropgeleiden sterker differentieert tussen willen blijven en het zoeken naar een andere baan dan bij lageropgeleiden (hypothese 5). In lijn met het psychologische vertrekproces waarin werknemers meerdere stadia afleggen voordat men daadwerkelijk vertrekt (Blau, 1993; 1994) stelden we ook dat het opleidingsniveau uitmaakt in het nemen van de stap van enkel nadenken over een andere baan naar het daadwerkelijk zoeken van een andere baan (hypothese 6).

De resultaten verwerpen echter de hypothese dat ontevreden lageropgeleiden vaker dan ontevreden hogeropgeleiden blijven hangen in het nadenken over een andere baan in plaats van te gaan zoeken naar een andere baan. Mogelijk is het vertrekproces met verschillende fases slechts een theoretisch aannemelijk idee en blijkt in praktijk dat het enkel nadenken over een andere baan niet altijd keurig voorafgaat aan het zoeken van een andere baan bij een andere werkgever. Het enkel nadenken en niet zoeken naar een baan bij een andere werkgever laat onbelicht dat werknemers in praktijk ook een reeks van andere keuzes kunnen maken. Ontevreden denkers kunnen tot de conclusie komen dat men toch iets aan het huidige werk moet veranderen, dat men eens met een leidinggevende moet praten of dat men eerst intern eens gaat zoeken naar een andere functie. Deze alternatieven, zoals ook opgemerkt door Vandenberg en Nelson (1999), zijn in dit onderzoek niet onderzocht, maar kunnen wel een verklaring bieden voor het niet vinden van bewijs voor de laatste hypothese. Hirshman's (1970) klassieke onderscheid in werknemerreacties op baanontevredenheid verdeeld in de actieve vormen als 'exit' en 'voice' en passieve vormen als 'loyalty' en 'neglect' zouden hieraan kunnen bijdragen. Hierbij zou de vraag kunnen worden gesteld of en waarom er tussen opleidingsniveaus verschillen zijn in het type reactie op baanontevredenheid.

\section{Beperkingen van deze studie}

Voor de analyses met baanontevredenheid als afhankelijke variabele bleek dat we niet alle werknemers uit het totale bestand konden behouden door de strenge criteria voor de schaalscores voor verschillende werkkenmerken: alle items moesten zijn beantwoord om meegenomen te worden. Dit leidde tot een reductie van het aantal mee te nemen observaties. Ook in het tweede onderzoeksdeel was er sprake van een groot aantal ontbrekende waarden omdat er naast antwoordcombinaties die leidden tot de door ons gehanteerde indeling (blijvers, denkers en zoekers) andere combinaties mogelijk zijn die in dit onderzoek niet zijn meegnomen. Wat betreft deze ongeveer 8.000 werknemers die in dit onderzoek niet te classificeren waren als blijver, denker of zoeker, is het mogelijk dat er andere motieven om te vertrekken een rol spelen. Gesthuizen en Dagevos (2005) onderscheidden naast 'vastzittenden' en 'verbetering zoekenden' ook een categorie 'goudzoekers'. Werknemers in deze laatste categorie hebben geen reden om weg te gaan (ze willen blijven), maar vertonen wel zoekgedrag. Op het moment dat ze tegen iets aanlopen dat qua arbeidsvoorwaarden beter is zullen ze toch naar een andere werkgever "hoppen". 
Andere kanttekeningen die geplaatst dienen te worden zijn dat het onderzoek cross-sectioneel van aard is waardoor er geen causale conclusies kunnen worden getrokken op basis van de gevonden relaties. Tevens kunnen we geen uitspraken doen over daadwerkelijk vertrek bij de organisatie. Hoewel uit ander onderzoek blijkt dat vertrekintenties hiervan een goede voorspeller zijn (Griffeth et al., 2000) is het aan te bevelen om op basis van longitudinale data uitspraken te doen over het feitelijke vertrekgedrag.

\section{Implicaties van deze studie}

Deze studie laat zien dat het opleidingsniveau uitmaakt in wat werkenden ontevreden maakt met hun werk en in welke mate men hierdoor zoekgedrag onderneemt om deze persoonlijk gebrekkige aansluiting met het werk te herstellen. Aan de kant van het voorkomen van zo'n misfit moet (HR) beleidsmakers zich realiseren dat voor lageropgeleid personeel salarisontevredenheid en een hoge werkdruk relatief sterkere redenen zijn voor baanontevredenheid dan voor hogeropgeleiden. Het bieden van meer taakvariatie of loopbaanmogelijkheden weegt voor lageropgeleiden minder zwaar dan de extrinsieke werkkenmerken. Voor bedrijven in economisch zwaar weer zullen vooral de extrinsieke werkkenmerken onder druk komen te staan: men moet meer doen met minder mensen en minder financiële middelen. Dat kan onder lageropgeleiden leiden tot grotere baanontevredenheid. Bovendien blijkt dat lageropgeleiden deze ontevredenheid minder vaak omzetten in zoekgedrag. Hiermee onderschrijft deze studie de stelling dat lageropgeleiden een groter risico lopen om vast te komen zitten in een baan die ze niet meer past. De zorg hierbij is dat wanneer deze situatie zich te lang voortsleept er een verhoogd risico is op uitval of onvrijwillige uitstroom.

Het bevorderen van de vrijwillige mobiliteit in van-werk-naar-werk trajecten wordt vaak genoemd als een oplossing om de inzetbaarheid werknemers te vergroten en hiermee dreigende werkloosheid te vermijden. Heyma, Van der Werff en Prins (2009) tonen echter dat externe mobiliteit niet altijd een garantie biedt voor betere inzetbaarheid in termen van een geringere kans werkloos te raken. Interne mobiliteit zou tot een kleinere kans op werkloosheid leiden. Om voor laagopgeleiden met minder groei- en carrièrewensen zulke bedrijfsinterne verbeteringen te creëren zijn creatieve alternatieven dan ook gewenst. Aan de kant van de misfit tussen werknemer en het huidige werk valt te denken aan job crafting interventies gericht op het maken van kleine aanpassingen in de huidige baan, zodat persoon en baan beter gaan en blijven passen (Berg, Dutton \& Wrzesniewski, 2008). Aan de kant van het herstellen van een misfit in een andersoortige baan kunnen werkgever minder radicale transities organiseren waarbij werknemers met nog een been in de organisatie blijven staan. Zo is er recentelijk aandacht voor initiatieven als intrasectorale mobiliteitsnetwerken of 'gedeeld werkgeverschap' waarin werknemers in een zogenaamde mozaïekbaan werken die bestaat uit taken bij meerdere regionale werkgevers uit verschillende sectoren (Dorenbosch \& Sanders, 2010). 


\section{Literatuur}

Althauser, R.P. \& Kalleberg, A.L. (1990). Identifying career lines and internal labor markets within firms: a study in the interrelationships of theory and methods. In R.L. Breiger, (Ed.), Social Mobility and Social Structure. Cambridge: Cambridge University Press.

Becker, G. (1964). Human Capital: A Theoretical and Empirical Analysis, with Special Reference to Education. New York: National Bureau of Economic Research.

Berg, J.M., Dutton, J.E. \& Wrzesniewski, A. (2008). What is job crafting and why does it matter? University of Michigan: Centre of Positive Organizational Scholarship.

Blau, G. (1993). Further exploring the relationship between job search and voluntary individual turnover. Personnel Psychology, 46, 313-330.

Blau, G. (1994). Testing a two-dimensional measure of job search behavior. Organizational Behavior and Human Decision Processes, 59, 288-312.

Bossche, S.N.J. van den, Hupkens, C.L.H., Ree, S.J.M. de \& Smulders, P.G.W. (2007). Nationale Enquête Arbeidsomstandigheden 2007: Methodologie en globale resultaten. Hoofddorp: TNO.

Büchel, F., De Grip, A. \& Mertens, A. (Eds.). (2003). Overeducation in Europe: Current Issues in Theory and Policy. Cheltenham, UK: Edward Elgar.

Caplan, R. D. (1983). Person-environment fit: Past, present, and future. In C. L. Cooper (Ed.), Stress research. New York: Wiley.।

Dorenbosch, L.W. \& Sanders, J. (2010) Gedeeld werkgeverschap naar Frans voorbeeld: veelbelovend van-werk-naar-werk instrument voor het midden- en kleinbedrijf? Over.Werk, 2, 44-49.

Edwards, J. R. (1991). Person-job fit: a conceptual integration, literature review and methodological critique. International Review of Industrial/Organizational Psychology, 6, 283-357.

Evers, M., Ybema, J.F., \& Smulders, P. (2006). Arbeidstevredenheid: gevolg van werkkenmerken, werkwaarden of beide? Gedrag \& Organisatie, 19, 37-48.

Forrier, A. \& Sels, L. (2005). Het concept employability: een puzzel met veel stukjes. Tijdschrift voor HRM, 3, 47-73.

Gesthuizen, M. \& Dagevos, J. (2005). Arbeidsmobiliteit in goede banen. Oorzaken van baan en functiewisselingen en gevolgen voor de kenmerken van het werk. Den Haag: Sociaal Cultureel Planbureau.

Gesthuizen, M. (2009). Job characteristics and voluntary mobility in The Netherlands Differential education and gender patterns? International Journal of Manpower, 30, 549-566.

Griffeth, R. W., Hom, P.W., \& Gaertner, S. (2000). A meta-analysis of antecedents and correlates of employee turnover: Update, moderator tests, and research implications for the next millennium. Journal of Management, 26, 463-488.

Halman, L.C.J.M., \& Muller, H. (2006). Contemporary work values in Africa and Europe: Comparing orientations to work in Africa and European societies. International Journal of Comparative Sociology, 47, 117-143.

Harding, S. \& Hikspoors, F. (1995) New Work Values: In Theory and in Practice. International Social Science Journal, 145, 441-56.

Heyma, A, van der Werff, S. \& Prins, J. (2009). Baten van baan-baan mobiliteit. Amsterdam: SEO.

Hirshman, A. O. (1970). Exit, voice, and loyalty. Cambridge, MA: Harvard University Press.

Inglehart, R., Basáñez, M. \& Moreno, A. (1998) Human Values and Beliefs. A Cross-Cultural Sourcebook. Ann Arbor: The University of Michigan Press. 
Kalleberg, A.L. (1977). Work Values and Job Rewards: a Theory of Job Satisfaction. American Sociological Review, 42, 124-143.

Knoop, R. (1994).Work values and job satisfaction. Journal of Psychology, 128, 683-690.

Kristof, A., Zimmerman, R. D. \& Johnson, E. C. (2005). Consequences of individuals' fit at work: a meta-analysis of person-job, person-organization, person-group and personsupervisor fit. Personnel Psychology, 58, 281-342.

Lee, T.H., Gerhart, B., Weller, I. \& Trevor, C.O. (2008). Understanding voluntary turnover: Path-specific job satisfaction effects and the importance of unsolicited job offers. Academy of Management Journal, 51, 651-671.

Mincer, J. (1974). Schooling, Experience, and Earnings. New York: Columbia University Press.

Nauta, A., De Lange, A.H., \& Görtz, S. (2010). Lang zullen we leven, werken en leren. Een schema voor het begrijpen en beïnvloeden van inzetbaarheid gedurende de levensloop. Gedrag en Organisatie, 23, 136-157.

Raemdonck, I., de Grip, A., Segers, M. Thijssen, J. \& Valcke, M. (2008). Zelfsturing in leren en loopbaan als predictoren van employability bij laaggeschoolde werknemers. Gedrag \& Organisatie, 21, 386-405.

Ross, M., Schwartz, S.H., \& Surkiss, S. (1999). Basic Individual Values, Work Values, and the Meaning of Work. Applied Psychology: An International Review, 48, 49-71.

Sanders, J. \& de Grip, A. (2004). Training, task flexibility and the employability of low skilled workers. International Journal of Manpower, 25, 73-89.

Van den Broeck, A., Van Ruysseveldt, J., \& De Witte, H. (in druk). Does an intrinsic work value orientation strengthen the impact of job resources? A perspective from the job demands-resources model. European Journal of Work and Organisational Psychology.

Vandenberg, R.J., Nelson, J.B., (1999). Disaggregating the motives underlying turnover: when do intentions predict turnover behavior? Human Relations, 10, 1313-1336.

Vroom, V.H. (1964). Work and motivation. New York: Wiley.

de Vroome, E.M.M., Smulders, P.G.W. \& Houtman, I.L.D. (2010) Longitudinale studie naar oorzaken en effecten van presenteïsme. Gedrag \& Organisatie, 3, 194-212.

Wanous, J.P., Reichers, A.E. \& Hudy, M.J. (1997). Overall Job Satisfaction: How Good Are Single-Item Measures? Journal of Applied Psychology, 82, 247-252.

Warr, P. (2008). Work values: Some demographic and cultural correlates. Journal of Occupational and Organizational Psychology, 81, 751-775.

Yankelovich,D., Zetterberg, H., Strümpel, B., Shanks, M. et al. (1985) The World at Work. An International Report on Jobs, Productivity and Human Values. New York: Octogon Books.

Zwinkels, W., Ooms, D. \& Sanders, J. (2009). Omvang, aard en achtergronden van baanbaan-mobiliteit. Den Haag: RWI/TNO. 